$10-14-2020$

\title{
Never Letting a Good Crisis Go to Waste: Canadian Interdiction of Asylum Seekers
}

\author{
Sean Rehaag \\ Osgoode Hall Law School of York University, srehaag@osgoode.yorku.ca \\ Janet Song \\ janetleesong@gmail.com \\ Alexander Toope \\ alextoope@gmail.com
}

Source Publication:

Frontiers in Human Dynamics v.2 (October 2020)

Follow this and additional works at: https://digitalcommons.osgoode.yorku.ca/scholarly_works

Part of the Law Commons

\section{Repository Citation}

Rehaag, Sean; Song, Janet; and Toope, Alexander, "Never Letting a Good Crisis Go to Waste: Canadian Interdiction of Asylum Seekers" (2020). Articles \& Book Chapters. 2819.

https://digitalcommons.osgoode.yorku.ca/scholarly_works/2819

This Article is brought to you for free and open access by the Faculty Scholarship at Osgoode Digital Commons. It has been accepted for inclusion in Articles \& Book Chapters by an authorized administrator of Osgoode Digital Commons. 


\section{OPEN ACCESS}

Edited by:

Jaya Ramji-Nogales,

Temple University, United States

Reviewed by:

Rachel Settlage,

Wayne State University, United States

Catherine Holtmann,

University of New Brunswick

Fredericton, Canada

*Correspondence:

Sean Rehaag

srehaag@osgoode.yorku.ca

tThese authors have contributed equally to this work

Specialty section: This article was submitted to

Refugees and Conflict,

a section of the journal

Frontiers in Human Dynamics

Received: 30 July 2020 Accepted: 04 September 2020

Published: 14 October 2020

Citation:

Rehaag S, Song J and Toope A (2020) Never Letting a Good Crisis Go to

Waste: Canadian Interdiction of Asylum Seekers.

Front. Hum. Dyn. 2:588961. doi: 10.3389/fhumd.2020.588961

\section{Never Letting a Good Crisis Go to Waste: Canadian Interdiction of Asylum Seekers}

\author{
Sean Rehaag ${ }^{1 *}$, Janet Song ${ }^{2 \dagger}$ and Alexander Toope ${ }^{2 \dagger}$ \\ ${ }^{1}$ Centre for Refugee Studies \& Osgoode Hall Law School, York University, Toronto, ON, Canada, ${ }^{2}$ Osgoode Hall Law School, \\ York University, Toronto, ON, Canada
}

This article examines two moments of crisis at Canada's border with the United States: the aftermath of September 11th' 2001 ("9/11") and the COVID-19 pandemic. The Canadian government leveraged both crises to offshore responsibilities for asylum seekers onto the United States. In the first case, Canada took advantage of U.S. preoccupations with border security shortly after 9/11 to persuade the United States to sign the Canada-U.S. Safe Third Country Agreement ("STCA") - an agreement that allows Canada to direct back asylum seekers who present themselves at land ports of entry on the Canada-U.S. border. In the second case, Canada used heightened anxieties about international travel during the COVID-19 pandemic to persuade the United States to block irregular border crossings that asylum seekers were increasingly using to circumvent the STCA. After reviewing Canada's successful use of these moments of crisis to persuade the United States to take on additional responsibilities for asylum seekers for whom Canada would have otherwise been responsible, the article discusses a recent Canadian Federal Court decision that may make all this political maneuvering moot. This decision found that Canada cannot send asylum seekers back to the United States without violating constitutional rights to life, liberty, and security of the person. Given past practice, however, we can expect the Canadian government to continue to pursue avenues to persuade the United States to take on additional responsibility for asylum seekers - and moments of crisis will be important drivers for those efforts.

Keywords: COVID-19, 9/11, refugees, asylum seekers, Canada, safe third country

\section{INTRODUCTION}

This article examines two moments of crisis at Canada's land border with the United States: the aftermath of 9/11 and the COVID-19 pandemic. The Canadian government leveraged both crises to offshore responsibilities for asylum seekers onto the United States.

The primary legal instrument we will be examining with respect to both these crises is the Canada-U.S. Safe Third Country Agreement ("STCA"). Under the terms of the STCA, subject to limited exceptions, asylum seekers attempting to enter Canada from the United States via an official land border port of entry are denied access to Canada's refugee determination system and returned to the United States (Government of Canada, 2002). The agreement works both ways-asylum seekers who attempt to enter the United States from Canada at a land border crossing can also be turned back to Canada (Government of Canada, 2002). The rationale behind this agreement is that 
asylum seekers are expected to claim refugee protection in the first safe country they arrive in-currently, the United States is the only country designated as a safe third country under Canada's Immigration and Refugee Protection Act (S.C., 2001, c. 27; Government of Canada, 2002). There is an important limitation to the STCA: it does not apply to asylum seekers who enter Canada "irregularly" by circumventing official ports of entry along the land border. As such, asylum seekers who cross into Canada irregularly cannot be returned to the United States and are thus eligible to claim asylum in Canada (Government of Canada, 2002; Smith, 2019).

The first crisis explored in this article-the terrorist attacks on the World Trade Center in New York City on 9/11was a catalyst for the Canadian government to secure the implementation of the STCA. The United States had long refused to enter into such an agreement despite pressure from Canada, knowing that it would significantly increase the number of asylum seekers for whom the United States, rather than Canada, was responsible. Eventually, the STCA's ratification was a quid pro quo: the United States accepted additional responsibility for asylum seekers in return for Canada's implementation of enhanced security measures and greater collaboration along the U.S.-Canada border, at a time when such measures were U.S. priorities (US Department of State, 2002; Meyers, 2003; Macklin, 2005, p. 417). In addition, the Bush administration saw political advantages to announcing the successful negotiation of the STCA, which offered an occasion to contrast purportedly strong U.S. border security measures with perceived vulnerabilities in Canadian border control practices (Macklin, 2003, p. 16-17; House of Representatives, 2002).

The second crisis analyzed in this paper-the current COVID-19 global pandemic-was channeled by the Canadian government to persuade the United States to block irregular border crossings that asylum seekers were increasingly using to circumvent the STCA. These irregular border crossings had begun to pose political risks to Canada's governing Liberal party: the sudden influx of irregular crossings following the 2016 U.S. presidential election garnered strong criticism from opposing political parties and certain members of the Canadian public (Vigil and Abidi, 2018, p. 55; Harris, 2019; Jansa et al., 2019). Once again, a crisis presented an opportunity: when Canada negotiated border closures with the United States during the COVID-19 pandemic, the Trump administration was persuaded to allow Canada to direct back to the United States asylum seekers caught crossing the border irregularly, functioning as a de facto expansion of the STCA (Government of Canada, 2020a; Russell, 2020). While this was ostensibly justified on public health grounds, from the Canadian government's perspective the policy had little to do with protecting public health. Rather, it aimed to address critiques raised by political opponents about the Liberal party failing to stem the flow of asylum seekers crossing the land border irregularly to avoid the STCA (Hwang, 2017; Canadian Council for Refugees, 2020b).

In both cases, Canada successfully harnessed moments of crisis to convince the United States to take on greater obligations toward asylum seekers. It is ironic that what the Trump administration has attempted to achieve through overt antiimmigrant rhetoric and policies (i.e., "build a wall" against asylum seekers), Canada achieved on its southern border through less inflammatory but more calculating means. It is troubling that Canada has managed to maintain an international reputation for progressive immigration and refugee policies, while quietly leveraging crises to establish interdiction agreements with the United States that prevent asylum seekers from accessing refugee protection in Canada.

A recent Canadian Federal Court of Canada decision, however, may make all this political maneuvering moot (Federal Court of Canada, 2020). This decision found that Canada cannot send asylum seekers back to the United States without violating constitutional rights to life, liberty, and security of the person. Thus, the primary rationale for supporting the STCA - namely, that the United States is a safe country for asylum seekers-has now been invalidated by a Canadian court. This makes the Canadian government's underlying motivations behind the agreement appear plain: to offload responsibility for asylum seekers to the United States irrespective of whether the United States is safe for asylum seekers. The Canadian government has continued to pursue that agenda by appealing the Federal Court decision, and by continuing to implement the STCA and its de facto extension, pending the outcome of that appeal. Moreover, regardless of the outcome of the appeal, we can expect the Canadian government to continue pressuring the United States to take on additional responsibility for asylum seekers-and moments of crisis will be important drivers in those efforts.

\section{I: POST-9/11 U.S. SECURITY CONCERNS AND THE STCA}

For several years before the STCA was officially signed, Canada had been pressing for an interdiction agreement with the United States to manage the flow of asylum seekers (Macklin, 2005, p. 372-373). The United States consistently refused to enter into such an agreement, as it would prevent thousands of asylum seekers from leaving the United States for Canada each year, thus significantly increasing the number of asylum seekers for whom the United States is responsible. Consider that from 1995 to 2001, 60 to 70 percent of asylum seekers entering Canada came through the United States first (394). Indeed, in 2001 alone, 13,000 asylum seekers arrived in Canada from the United States, while only 200 traveled in the other direction (394-395).

Prior to 9/11, Canada made little progress in its efforts to persuade the United States to close off this route for asylum seekers. However, "the $9 / 11$ attack gave [...] that area a new impetus” (Adelman, 2002, p. 27; Moore, 2007, p. 262; Settlage, 2012, p. 150). On October 29, 2001, George W. Bush directed U.S. personnel "to begin harmonizing customs and immigration policies with those of Canada as well as Mexico" (Adelman, 2002, p. 21). This led to negotiations between Canada and the United States that culminated in the U.S.-Canada Smart Border Action Plan ("Action Plan"), which sets out a 30-point plan for collaboration, including coordination on refugee processing and 
the enactment of counter-terrorism legislation (US Department of State, 2002).

President Bush and Prime Minister Jean Chrétien met at the Ambassador Bridge in Detroit, Michigan in September 2002 to provide a status report on the Action Plan, a discussion that included the STCA and other collaborative security measures between the United States and Canada (Meyers, 2003, p. 4). For the United States, the STCA was a quid pro quo that secured Canada's agreement to the Action Plan (Macklin, 2005, p. 417; Meyers, 2003). For Canada, the Action Plan represented an opportunity to leverage U.S. security concerns related to border security after $9 / 11$ and the perceived security vulnerabilities of Canada's immigration regime, to convince the United States to sign the STCA (Macklin, 2003, p. 16-17).

As the Action Plan was being negotiated, the rhetoric surrounding security tended to overshadow Canada's attempt to offload responsibility for asylum seekers to the United States. For example, consider Congressional testimony by Kelly Ryan, then Deputy Assistant Secretary of State in the Bureau of Population, Refugees, and Migration at the U.S. Department of State. Ryan praised Canada's eagerness to collaborate with the United States on enhancing security measures, declaring that "the United States and Canada share a common determination to combat terrorism" and a "willingness to develop mutual approaches to our common security." The examples cited by Ryan for Canada's "tangible security improvements" included, among others, advanced information sharing on international air passengers, "integrated border enforcement teams" of enforcement personnel, and sharing fingerprints and other criminal record information (House of Representatives, 2002).

With overarching national security preoccupations in the United States post-9/11, criticisms of Canada's supposed lack of border security were common. Ryan's testimony is but one example of the emphasis placed on Canada's perceived lack of border security in the fight against terrorism. Such rhetoric directly tied terrorism to regulating the flow of asylum seekers, showcasing that "the glue binding asylum seeker and terrorist adheres just enough that invoking the former suffices to bring the latter to mind" (Macklin, 2005, p. 410). Consider, for example, the critiques of Canada for insecure borders and for insufficient measures to prevent organized crime and terrorism, in the Congressional testimony of Mark Krikorian, the Executive Director of the Center for Immigration Studies (House of Representatives, 2002):

the United States has an important security interest in Canada's applying the safe third country proposal and incorporating it into its own asylum system. According to the Canadian equivalent of our asylum, more than 50 terrorist groups have established themselves in Canada, partly because of a laxity of that country's asylum system. [...] [I]deally, all applicants for asylum should be detained until their cases are decided. So, sure, I would rather have a potential terrorist [locked] up in New Jersey than working in Manitoba.

This "laxity" referenced by Krikorian is based on the argument that it is easier to become a refugee in Canada in comparison to the United States, and that Canada provides more access to public health care, legal aid, and other social assistance to asylum seekers, thus further incentivizing individuals to claim asylum (Macklin, 2005, p. 412). One would assume that Canada would unequivocally reject critiques of its supposedly "lax" approach to border control, especially considering that none of those responsible for the 9/11 attacks entered the United States from Canada (or were asylum seekers generally). However, instead of actively combatting misinformation, Canada leaned into the link between asylum seekers and terrorists, as doing so helped secure an agreement they had been pursuing for years. As Macklin (2003) explains, it was politically valuable for the United States to place scrutiny on a perceived lack of security measures employed by their neighbor to the North:

Even if US policy makers know that the Canadian refugee system plays a minimal role in the presence of terrorists on US soil, it may be worth the cost of adjudicating several thousand additional asylum claims to reinforce the perception that the Canadian refugee system is dangerously lax, and that the United States can and will do a better job (18).

Whether real or imagined, these negative perceptions of Canada's border control regime in the aftermath of $9 / 11$, and Canada's tacit encouragement of these perceptions, appear to have played a role in finally persuading the US to agree to the STCA.

\section{II: COVID-19, THE STCA AND CLOSING UNOFFICIAL PORTS OF ENTRY}

Long before COVID-19, the Canadian government faced considerable pressure from political opponents to expand the STCA to cover irregular border crossings (Jansa et al., 2019, p. 38; Panetta, 2019). This was largely due to the belief that asylum seekers crossing irregularly are "illegal" and "jumping the queue" (Vigil and Abidi, 2018, p. 55; Harris, 2019). Despite this being false-international law recognizes the right to seek asylum and prohibits the imposition of penalties on asylum seekers who travel irregularly-these anti-migrant sentiments spread in Canadian political discourse and became a cornerstone of Conservative election campaigns (Jansa et al., 2019, p. 38; Canadian Council for Refugees, 2020a).

Opposition to asylum seekers who cross the border irregularly increased following U.S. President Donald Trump's 2016 election win. In line with the anti-migrant and xenophobic rhetoric touted during his campaign, Trump signed several executive orders targeting migrants, including stripping certain groups of Temporary Protected Status, and imposing a "Muslim Travel Ban" (Jansa et al., 2019, p. 38). The results of anti-migrant rhetoric and policies were felt along Canada's border: in December 2016, 1 month after the November 2016 U.S. election, 305 asylum seekers entered Quebec from the United States irregularly; this was a 1,400\% increase from December 2015 (Proctor, 2017, p. 2). The number of asylum seekers crossing irregularly into Canada continued to increase in the following years, with nearly 50,000 irregular border crossings recorded between 2017 and 2019 (Smith, 2019). It is important to note 
that the vast majority of these crossings were not clandestine, but rather were made at highly monitored "unofficial" ports of entry, such as Roxham Road at the New York-Quebec border, where the Canadian government has built border infrastructure to process irregular border crossers seeking asylum (Smith, 2019).

Critics suggested that this sudden influx in migration at unofficial ports of entry was proof that Trudeau's Liberal government had "lost control of the border" and were being soft on "illegal" migration, despite the legal and generally orderly nature of the crossings (Panetta, 2019; Smith, 2019). Given these mounting criticisms, the Liberal government had an interest in expanding the STCA to unofficial ports of entry. They also had an interest in doing so quietly to avoid undermining efforts to present a progressive and pro-migrant image, including through Trudeau's highly publicized tweet stating: "To those fleeing persecution, terror \& war, Canadians will welcome you, regardless of your faith. Diversity is our strength \#WelcomeToCanada" (Austen, 2017; Trudeau, 2017). Canada, however, had little leverage in renegotiating the STCA with the United States, given the Trump administration's reluctance to take on additional responsibility for asylum seekers (Smith, 2019). Unsurprisingly, there was initially very little movement on this front.

This changed quickly during the COVID-19 pandemic, which presented an opportunity for the Canadian government to secure an agreement that serves as a de facto expansion of the STCA, justified ostensibly on public health grounds. The Canadian government's initial plan at the onset of the pandemic was that asylum seekers who crossed the border irregularly would be screened, sheltered, and isolated for 14 days (Government of Canada, 2020b; The Canadian Press, 2020). However, on March 20, 2020, Prime Minister Justin Trudeau reversed course, announcing that asylum seekers crossing into Canada irregularly would be denied entry and returned to the United States (Russell, 2020). This was implemented under Canadian law through a series of Orders in Council (see e.g., Government of Canada, 2020a), which are instruments available to the executive branch of the Canadian government that are enforceable without action by the legislature-in this case authorized by the Quarantine Act (S.C., 2005, c. 20). Trudeau stated that these emergency measures would be lifted once it is safe to do so (The Canadian Press, 2020).

There is reason to be skeptical that this action was taken solely to protect public health during the COVID-19 pandemic. There are other measures that would effectively protect public health without requiring the closure of the border to asylum seekers. As the Canadian government initially proposed (The Canadian Press, 2020), there could have been immediate health checks at unofficial ports of entry and mandatory quarantines. Such a strategy would be in line with the requirements imposed on other travelers entering Canada, including those with less "essential" reasons to travel to Canada (Rehaag, 2020). Yet, despite little evidence that asylum seekers are any more likely than other travelers to carry COVID-19 or to violate selfisolation measures, they were uniquely targeted (Hwang, 2017; Canadian Council for Refugees, 2020b; Government of Canada, 2020a,b,c).
There is also reason to believe that closing off this route into Canada may actually increase, rather than decrease, public health risks in Canada. The experience with the STCA has taught us that when the law was used to block paths into Canada at official ports of entry, asylum seekers pursued other routes into the country, including by crossing the border irregularly at unofficial ports of entry like Roxham Road (Settlage, 2012, p. 171). Given that asylum seekers attempting to avoid the STCA by crossing the border irregularly will, during the COVID-19 pandemic, be returned to the United States if they are caught crossing, they have a strong incentive to make clandestine crossings into Canada. That means crossing at remote and risky sites, perhaps with the assistance of smugglers, and without health screenings or quarantines. In other words: the Canadian government has taken safe, well-monitored routes into Canada at places like Roxham Road, and replaced them with unsafe, unmonitored routes that may exacerbate public health risks during the pandemic.

While the public health rationale for closing off unofficial ports of entry like Roxham Road seems decidedly weak, the same cannot be said about the political justification. The Trudeau government achieved a policy outcome that it had been pursuing for years, and in so doing made a political headache go away: the route that tens of thousands of asylum seekers have used to enter Canada since Trump was elected has been blocked, at least temporarily, and the Liberal government's Conservative opponents have been silenced.

\section{CONCLUSION}

The Canadian government's proclivity to channel American perceptions of the Canadian border as a threat to U.S. national security-whether due to terrorism or pandemics-to convince the United States to take on greater obligations toward asylum seekers, is a lesson in diplomacy. It is worthy of note that Canada achieved this under two Republican administrations that both championed strict border enforcement and restricting "illegal" immigration. Canada has not employed the blatant antiimmigrant rhetoric exemplified in the United States under the Trump administration but has nonetheless "built a wall" against asylum seekers through the STCA, and more recently during the COVID-19 pandemic. Although the Canadian government espouses progressive values, in practice, closed-door diplomacy with respect to the interdiction of asylum seekers has undercut these values and Canada's international obligations.

Recently, the unconstitutionality of these tactics has been recognized by the Federal Court of Canada, which in July 2020 issued a landmark decision invalidating the STCA (Federal Court of Canada, 2020). In this decision, Justice McDonald found that the United States is not safe for asylum seekers, and that "...the risk of detention in the United States for the sake of 'administrative' compliance with the provisions of the STCA cannot be justified" (138). Based on evidence describing inhumane conditions of detention, the use of detention as a penalty against asylum seekers, and increased risks of deportation to face persecution for detained asylum seekers in the United States, the Federal Court found that directing 
back asylum seekers to the United States under the STCA violates constitutional rights to life, liberty, and security of the person (138-140).

The Federal Court suspended the effect of this decision for 6 months, to provide the Canadian government with an opportunity to appeal or to otherwise respond (163).

On August 21, 2020, Canadian Public Safety Minister Bill Blair confirmed that the government filed an appeal of the decision, citing legal and factual errors as a rationale for the appeal (Tunney, 2020). This is perhaps not surprising. A previous challenge to the constitutionality of the STCA when the agreement was first implemented was successful in the Federal Court, on the basis that, even then, the United States was not safe for asylum seekers (Federal Court of Canada, 2007). However, the Canadian government successfully appealed that decision on technical grounds, including that the parties to the litigation lacked standing before the courts since none of the parties had been directly turned away under the STCA (Federal Court of Appeal, 2008). The more recent constitutional case does not suffer from the same technical challenges, partly because litigants were selected who were directly impacted by the STCA and who thus clearly have standing. That means that any appeal will need to address the substantive question of whether the United States is safe for asylum seekers-in other words, whether asylum seekers returned to the United States under the STCA encounter circumstances where their rights to life, liberty, and security of the person, as protected by section 7 of the Canadian Charter of Rights and Freedoms, are respected. Given that these circumstances include deeply problematic conditions of detention in the United States, as set out in the Federal Court's factual findings, we think it will be difficult for the Federal Court of Appeal to overturn this decision. We therefore echo calls made by others for the Canadian government to cease its appeal in

\section{REFERENCES}

Adelman, H. (2002). Canadian borders and immigration post 9/11. Int. Migrat. Rev. 36, 15-28. doi: 10.1111/j.1747-7379.2002.tb00066.x

Austen, I. (2017, January 28). In Canada, Justin Trudeau Says Refugees Are Welcome. The New York Times. Available online at: https://www.nytimes.com/ 2017/01/28/world/canada/justin-trudeau-trump-refugee-ban.html (accessed July 11, 2020).

Canadian Council for Refugees (2020a). Media Release: Organizations Welcome Court Ruling on Safe Third Country. Available online at: https://ccrweb.ca/en/ ruling-safe-third-country (accessed September 2, 2020).

Canadian Council for Refugees, Amnesty International Canada, Canadian Association of Refugee Lawyers, and BC Civil Liberties Association (2020b, April 2). Media release: call for border to be reopened to refugees. Canadian Council for Refugees. Available online at: https:// ccrweb.ca/en/media/call-border-be-reopened-refugees-02-04-2020 (accessed July 11, 2020).

Federal Court of Appeal (2008). Canadian Council for Refugees $v$ Canada, 2008 FCA 229.

Federal Court of Canada (2007). Canadian Council for Refugees v R, 2007 FC 1262.

Federal Court of Canada (2020). Canadian Council for Refugees v. Canada (Immigration, Refugees and Citizenship), 2020 FC 770.

Government of Canada (2002). Agreement between the Government of Canada and the Government of the United States of America for the Cooperation in the this matter, and to immediately suspend any removals under the STCA (Canadian Council for Refugees, 2020a).

Despite these calls, given past practice, it is reasonable to expect that the government will fully exhaust all appeals. While the appeal slowly makes its way through the Court system, the STCA, and the de facto extension of the agreement to unofficial ports of entry will remain in effect. This means that these "emergency" measures are likely to be in place for the duration of the pandemic and potentially the current U.S. administration, notwithstanding the constitutional problems identified by the Federal Court.

Regardless of the outcome of the appeal, it seems likely that Canada's efforts to convince the United States to take on additional responsibilities for and act as a wall against asylum seekers is not at an end. We can also anticipate that Canada will attempt to leverage future crises in these efforts.

\section{AUTHOR CONTRIBUTIONS}

All authors listed have made a substantial, direct and intellectual contribution to the work, and approved it for publication.

\section{FUNDING}

This research was supported in part by funding from the Social Sciences and Humanities Research Council, Osgoode Hall Law School and York University.

\section{ACKNOWLEDGMENTS}

The authors are grateful for feedback provided by Elise Mercier, Centre for Refugee Studies Research Lawyer.

Examination of Refugee Status Claims from Nationals of Third Countries. Available online at: https://www.canada.ca/en/immigration-refugeescitizenship/corporate/mandate/policies-operational-instructions-agreements/ agreements/safe-third-country-agreement/final-text.html (accessed July 11, 2020).

Government of Canada (2020a). Order in Council PC 2020-0442: Minimizing the Risk of Exposure to COVID-19 in Canada Order (Prohibition of Entry into Canada from the United States). Available online at: https://ordersin-council.canada.ca/attachment.php?attach=39383\&lang=en (accessed July 11, 2020).

Government of Canada (2020b). Order in Council PC 2020-0175: Minimizing the Risk of Exposure to COVID-19 in Canada Order (Mandatory Isolation). Available online at: https://orders-in-council.canada.ca/attachment.php? attach=38989\&lang=en (accessed July 11,2020).

Government of Canada (2020c). Order in Council PC 2020-0184: Minimizing the Risk of Exposure to COVID-19 in Canada Order (Prohibition of Entry into Canada from any Country other than the United States). Available online at: https://orders-in-council.canada.ca/attachment.php?attach $=38990 \&$ lang=en (accessed July 11, 2020).

Harris, K. (2019, December 12). Don't blame Trump: New study explores Canada's surge in asylum-seekers. CBC News. Available online at: https://www.cbc.ca/ news/politics/trump-immigration-trudeau-asylum-seekers-roxham-road- 1 . 5393071 (accessed July 11, 2020).

House of Representatives (2002). "United States and Canada safe third country agreement: hearing before the subcommittee on immigration, border security, 
and claims of the committee on the judiciary," in 107th Congress, Second Session (Washington, DC).

Hwang, J. (2017). Public Health Response and Health Status of Asylum Seekers: A Review of the International Literature and Implications for the Canadian Context. National Collaborating Centre for Infectious Disease, 352. Available online at: https://nccid.ca/publications/public-health-response-health-statusasylum-seekers-review-international-literature-implications-canadiancontext/ (accessed September 28, 2020).

Jansa, M., Klassen, A., Meinen, D., and Steinwand, C. (2019). Canada as a Frontline State? Populist Discourse, New Population Movements and the Canada-US Border Relationship. Balsillie School of International Affairs, 37-42. Available online at: https://www.balsillieschool.ca/wp-content/uploads/2019/ 02/Graduate-Fellows-Anthology-2019.pdf\#page $=43$ (accessed September 28, 2020).

Macklin, A. (2003). The Value(s) of the Canada-Us Safe Third Country Agreement. Caledon Institute of Social Policy, 1-23. Available online at: https://ssrn.com/ abstract $=557005$ (accessed September 28, 2020).

Macklin, A. (2005). Disappearing refugees: reflections on the Canada-Us safe third country agreement. Columbia Hum. Rights Law Rev. 36, 365-426. Available online at: https://ssrn.com/abstract $=871226$

Meyers, D. M. (2003). Does 'Smarter' lead to safer? An assessment of the border accords with Canada and Mexico. Migrat. Policy Inst. Insight 41, 1-16. doi: $10.1111 / 1468-2435.00251$

Moore, A. (2007). Unsafe in America: a review of the U.S.-Canada safe third country agreement. Santa Clara Law Rev. 47, 201-284. Available online at: https://digitalcommons.law.scu.edu/lawreview/vol47/iss2/1

Panetta, A. (2019, September 16). Canada decides: Trudeau faces charge he's undermined support for immigration. Politico. Available online at: https://www.politico.com/story/2019/09/16/canada-decides-trudeaufaces-charge-hes-undermined-support-for-immigration-1666087 (accessed July 11, 2020).

Proctor, B. (2017). Fleeing to Canada on Foot: Reviewing the CanadaU.S. Safe Third Country Agreement. Wilson Center - Canada Institute. Available online at: https://www.wilsoncenter.org/sites/default/files/media/ documents/article/fleeing_to_canada_on_foot_stca_final_04-04-2017.pdf (accessed July 11, 2020).

Rehaag, S. (2020, June 17). Whose travel is 'essential' during coronavirus: Hockey players or asylum-seekers? The Conversation (Canada). Available online at: https://theconversation.com/whose-travel-is-essentialduring-coronavirus-hockey-players-or-asylum-seekers-140239 (accessed July 11, 2020).
Russell, A. (2020, March 20). Coronavirus: Trudeau says irregular migrants will be turned away at Canada-US border. Global News. Available online at: https:// globalnews.ca/news/6707593/coronavirus-trudeau-says-irregular-migrantswill-be-turned-away-at-canada-us-border/ (accessed July 11, 2020).

S.C. (2001). Immigration and Refugee Protection Act, S.C. 2001, c. 27.

S.C. (2005). Quarantine Act, Statutes of Canada 2005, c.20.

Settlage, R. G. (2012). Indirect refoulement: challenging Canada's participation in the Canada-United States safe third country agreement. Wisconsin Int. Law J. 30, 142-188. Available online at: https://heinonline.org/HOL/P?h=hein. journals/wisint30\&i=148\&a=eW9ya3UuY2E

Smith, C. D. (2019). Changing US Policy and Safe-Third Country 'Loophole' Drive Irregular Migration to Canada. Migration Policy Institute. Available online at: https://www.migrationpolicy.org/article/us-policy-safe-third-countryloophole-drive-irregular-migration-canada (accessed September 28, 2020).

The Canadian Press (2020, March 17). COVID-19: Isolation required for Roxham Rd asylum seekers, Blair says. CTV News. Available online at: https://montreal. ctvnews.ca/COVID-19-isolation-required-for-roxham-rd-asylum-seekersblair-says-1.4857034 (accessed July 11, 2020).

Trudeau, J. (2017, January 28). Twitter Post, 3:20 PM. Available online at: https://twitter.com/JustinTrudeau/status/825438460265762816 (accessed July 11, 2020).

Tunney, C. (2020, August 21). Liberals appealing ruling striking down CanadaU.S. asylum agreement. CBC News. Available online at: https://www.cbc. $\mathrm{ca} /$ news/politics/safe-third-country-agreement-liberals-appeal- 1.5695386 (accessed August 28, 2020).

US Department of State (2002). U.S.-Canada Smart Border/30 Point Action Plan Update. Available online at: https://2001-2009.state.gov/p/wha/rls/fs/18128. htm (accessed July 11, 2020).

Vigil, Y. N., and Abidi, C. B. (2018). 'We' the refugees: reflections on refugee labels and identities. Refuge 34, 52-60. doi: 10.7202/1055576ar

Conflict of Interest: The authors declare that the research was conducted in the absence of any commercial or financial relationships that could be construed as a potential conflict of interest.

Copyright (c) 2020 Rehaag, Song and Toope. This is an open-access article distributed under the terms of the Creative Commons Attribution License (CC BY). The use, distribution or reproduction in other forums is permitted, provided the original author(s) and the copyright owner(s) are credited and that the original publication in this journal is cited, in accordance with accepted academic practice. No use, distribution or reproduction is permitted which does not comply with these terms. 